\title{
PROTECTING THE SEAS AND OCEANS OF THE WORLD BY MEANS OF SANCTIONS AND OTHER MEASURES OF PUBLIC INTERNATIONAL LAW
}

\author{
D. Ş. Paraschiv
}

\section{Daniel-Ştefan Paraschiv}

Faculty of Law and Public Administration, Râmnicu Vâlcea, "Spiru Haret" University, Râmnicu Vâlcea, Romania

*Correspondence: Daniel-Ştefan Paraschiv, 30 General Magheru St., Râmnicu Vâlcea, Vâlcea, Romania

E-mail: drept_vl.paraschiv.daniel@spiruharet.ro

\section{Abstract}

The maritime zones recognized under international laws - are formed from the high seas, with the riches at the bottom of the oceans and seas from this perimeter - which is regulated by international conventions, whose infringement may lead to the application of sanctions in conformity with the dispositions stipulated, or, in the lack of such dispositions, to taking other measures, such as repression or retaliation, which are considered, in the public international law, as being general sanctions included in the category of countermeasures.

At high seas serious acts of a criminal character are also committed, such as: piracy, illicit traffic of narcotics and psychotropic substances, etc., thus all states must cooperate in view of repressing these acts and sanctioning the culprits.

Key-words: international law of the sea, repressions, retaliation, maritime areas

\section{Introduction}

The seas and oceans, which cover approximately $70 \%$ of the planet's surface present a particular global interest for the proper development of navigation by all states concerned, due to the acute necessity to extend research in these areas, as well as for unexpected biological, mineral and energetic resources, necessary to the development of people's economy. Thus, the forming of the international law of the sea constitutes a major imperative for the protection of international maritime order, establishing principles and norms of conduct which imply, besides the rights and obligations, responsibilities imposed on the states. The nations have intuited for a long period of time the necessity of recognizing law for the equal usage of the sea by all the people, starting from the idea that the sea must be considered a good of common use for all the people. Nevertheless, in time, as a result of changing different objective conditions in the exploitation and capitalization of oceans and seas, diverse view concerning the usage of the global ocean have appeared. The conception itself upon the stretching of maritime areas and state laws to exploiting the riches they contain evolved depending on the possibilities of discovering the mysteries of the planetary ocean and the capacity to understand the development of marine flora and fauna.

Sanctions and other measures stipulated in the Montego Bay Convention for acts which breach the law of the sea

For a long period of time, the regulations regarding the law of the sea were mainly customary, as in the 12th to the 16th century, the practice of the property law with a tendency of monopoly of powerful states over a part of the seas "adjacent" to their coasts, up to the "adjacent sea" of other states was dominant. England, France and Holland objected to these pretensions reclaiming the liberty of navigation for their ships in the oceans and seas of the world. 
Becoming a great maritime power, England claimed, commencing with the 17th century, supremacy over the seas and oceans for its ships, thus creating the famous dispute between the conception of "mare liberum" expressed by the Dutch lawyer Hugo Grotius and the conception of "mare clausum" of the English John Selden.

In the framework of the Geneva Conference from 1958, based on the works of the International Law Committee four Conventions1 were adopted which regulate many aspects specific to marine law. Within the third Conference of the law of the sea, convoked by UNO, the UNO Convention regarding the law of the sea 2 was adopted, which represents a veritable "Constitution of the Sea", embodying a complex system of norms and principles, meant to coordinate reports between states in the domain of sea law.

In conformity with the international norms, in the present two maritime areas are

only in the following cases: if the consequences of the felony influence the coastal state; if the infraction may result in disturb the peace of the country or order in the territorial sea; if the assistance distinguished: those upon which the state coast exercits its prerogatives and those which derive from an international status. From the first category, there are: the territorial sea (up to 12 sea miles commencing from the base lines of all states), the continental shalf 3 and the exclusive economic one 4 , and the second consists of the high seas with the riches on the base of the oceans and sea, which form the maritime zone recognized under international law.

In conformity with international norms, responsibility for illicit acts committed in the territorial sea and the continental shelf is, principally, engaged in conformity with the legislation of every state which manages them, and for the acts committed in the area of international marine spaces, responsibility is established in conformity to international conventions, especially the Montego Bay Convention.

Being aware of the importance of maintaining legal order in the areas of international maritime spaces, in the very preamble of the Convention5, the state parties express their conviction that, by means of this Convention, they contribute to the reinforcement of peace, security, cooperation and friendly relationships between all nations, in conformity with the principles of justice and equality in rights, favouring economical and social progress of all the people in the world, according to the objectives and principles of the United Nations Organization, as they are stipulated in the United Nations Charter.

In the Convention more measures for the infringement of the norm are stipulated, whose diversity is generated by the multitude of situations which may be found in the domains regulated.

Generally, measures that acquire a sanctioning character are ordered by the state parties, for the cases and according to the competences established by means of the dispositions embodied in this international Convention. Thus, in the art. 27, entitled: "Penal jurisdiction on board of a foreign ship", it is shown that the coastal state must exercite penal jurisdiction on board a foreign ship which passes through the territorial sea, proceeding to the arrest of persons or accomplishing certain acts of penal research, as a result of an

\footnotetext{
${ }^{1}$ The Convention regarding the continental shelf, the Convention concerning fishing and preserving biological resources of the high seas, the Convention regarding the high seas and the Convention referring to the territorial sea and the contiguous area.

${ }^{2}$ Adopted at Montego Bay, on the 10th of December 1982.

${ }^{3}$ The continental shelf of a coastal state embodies the seabed and the underground submarine regions situated beyond the territorial sea, through all natural extension of land territory of this state, until the external limit of continental margins or to a distance of 200 sea miles from the baselines from which the width of territorial seas is measured, when the external limit of the continental margins is situated at an inferior distance (art. 76 from the Montego Bay Convention).

${ }^{4}$ The maximum width is of 200 miles from the baselines (art. 57 of the Montego Bay Convention).

${ }^{5}$ Adopted on the 10th of December 1982, at Montego Bay (Jamaica), at the third UNO Conference regarding the law of the sea, entered in force on the 16th of November 1994, ratified by Romania by the Law no. 110 from the 10th of December 1996 (Official Gazette of Romania, no. 300/21 November 1996).
} 
infringement committed on board of this ship while passing, however of local authorities was required by the captain of the ship or a diplomatic agent or a consular officer of the flag state; if these measures are necessary in order to repress illicit traffic of narcotics and other psychotropic substances.

Referring to the civil jurisdiction towards foreign ships, the coastal state will be able to take measures of execution or preservation regarding these ships, but only for liabilities incurred or responsibility for these vessels or during and in view of the passing through the waters of the coastal state.

In the circumstance of breaching coastal state reglementations on straits, by means of transit by a ship or aircraft which benefits from sovereign immunity, the state under whose flag the ship is operating bears the international responsibility for any loss or damage which may result from it for the coastal states.

According to art. 73 pt. 1 in the Convention, the coastal state, in exercising its sovereign rights of exploitation, preservation and management of biological resources from the exclusive economic area, may take any measure, including the approach, inspecting, sequestration and juridical pursuit as to ensure compliance with laws and regulations adopted in conformity with the present Convention6.

Sanctions stipulated by the coastal state for breaching rules and regulations concerning fishing, in the exclusive economic zone, do not include prison sentences, except the case when interested states agree upon it, "and no corporal sentence" (art. 73 pt. 3).

In case of collision or any other navigation incident in the high seas, of nature to engage penal or disciplinary responsibility of the captain or any other person in service of the ship, penal or disciplinary pursuit may be performed only by the juridical or administrative authorities of the state flag or of the state whose citizenship is detained by those in cause. The flag state may order the retention or immobilization of the ship for performing acts of investigation.

The measures of withdrawal of the commander patent, of the capacity certificate or of the permit may be disposed only by the state which issued these documents.

All the state parties must cooperate as to repress piracy in the high seas or in any other place not submitted to the jurisdiction of a state, taking measures of retention of pirat ships and aircrafts or captured by pirates. Also, they can arrest persons and seize the goods on board, after which the courts will order the punishments and concerning the ships, aircrafts or other goods retained or seized. Moreover, all the state parties will cooperate as to repress unauthorised broadcasts, aired on the high seas7, being able to arrest any guilty person who will be brought to justice, or to immobilize any aircraft which transmits these broadcasts and seize the broadcasting device (art. 109 pt. 1 and 4 in the Convention).

In the contents of the Conventions other measures against states which breach its regulations are also stipulated, such as applying pecuniary penalties, in the case of producing damages to another state by polluting the environment, or at the demand to slow down the marine research works performed in the economic area or on the continental shelf of another state, in case the conditions to perform these works have not been respected.

\footnotetext{
${ }^{6}$ In art. 73 pt. 2 from the Convention it is shown that "The ship retained and its crew will be released immediately after depositing a bail or a proper guarantee", and at pt. 4 it is stipulated that "In case of retention or immobilization of a foreign ship, the coastal state will immediately notify the flag state, by means of adequate methods, the measures taken, as well as the sanctions pronounced as a consequence".

${ }^{7}$ According to art. 109 pt. 2 of the Convention, by unauthorised broadcasts, we understand: radio or television broadcasts destined to be recepted by the general public, aired on a ship or installation in the high seas, with the infringement of international regulations, except transmitting SOS.
} 


\section{Aspects regarding the international jurisdiction on international marine spaces}

In order to judge the disputes which appear from the interpretation and from applying the Convention, in conformity with art. 27 of the Montego Bay Convention, The International Court for the Law of the Sea was founded and headquartered in Hamburg8.

This court solved numerous cases, from which we submit to analysis the case concerning the Bluefin tuna (Australia and New Zeeland versus Japan)9. In this case, The International Court for the Law of the Sea took a series of measures, such as: Australia, Japan and New Zeeland must guarantee that they will not take measures which could affect or prolong the litigations submitted to the court; the same countries must guarantee that they will not take measures which could prevent the accomplishment of some decisions made by the court. Moreover, the three countries must guarantee that they will not exceed the annual quantities of Bluefin tuna allocated at the level mutually agreed upon by the parties; the state in cause which will refrain from performing an experimental fishing program which implies taking a Bluefin tuna capture, except the cases when the agreement of the other parties is present or when the experimental capture is reduced from the annual quantity allocated. It was also established that the three countries should immediately resume negotiations, with the objective of reaching an agreement concerning the measures for preserving and managing the Bluefin tuna species and continue to make efforts in the sense of reaching agreement with other states and fishing entities, engaged in Bluefin tuna fishing, aiming to promote the optimum usage objective of stock from the above mentioned fish species.

By studying the practice of the International Court of Justice, we observe that the international responsibility for acts performed at sea was established, in some cases, and by this court. Thus the Court admitted the invocation of the international responsibility of Albania for the reason that, in the year 1964, the british war ships which navigated in the Strait of Corfu, situated in the Albanian territorial waters, clashed into several mines, thus causing losses of human lives and material damage.

The Court decided that Albania was liable to warn foreign ships concerning the presence of mines in its territorial waters, motivating that this obligation is founded on "several general and acknowledged principles: principle of liberty concerning international communications and the obligation which is viable for every state, of not permitting its territory to be used in view of acts contrary to other states' rights" 10 .

In an earlier case11, the Permanent Court of International Justice decide in favour of Turkey, which condemned a French officer to prison and paying a fine because in the high seas, the French packet boat "Lotus" abandoned a Turkish ship which sank and eight Turkish citizens lost their lives.

\footnotetext{
${ }^{8}$ The Court is formed of 21 independent members who function within: Court Chamber of summary procedure, the Dispute Resolution Chamber on submarine spaces and room for settlement of disputes relating to the exploitation of the seas. One of the cases submitted to the International Tribunal for the Law of the Sea was one of Chile and the European Community in 2000 on the exploitation of swordfish stocks in the Pacific Ocean. The Chamber responsible with the case proceedings was formed of International Tribunal for the Law of the Sea by order of December 20, 2000, according to art. $15 \S 2$ of the Statute of the Tribunal. Finally, the parties reached an agreement which ended the dispute

${ }^{9}$ The dispute between Australia and New Zealand on the one hand and Japan on the other hand, dating from 1999, concerns the conservation and management of the blue fin tuna (a migratory species overseas, stipulated in the list of migratory species in the Appendix I of the United Nations Convention on the Law of the Sea). Of the cases judged by the International Tribunal for the Law of the Sea we mention: the Volga case (Russia vs. Australia) case regarding the territorial expansion of the Strait of Johor Singapore (Singapore vs. Malaysia) case regarding the MOX plant (Republic of Ireland vs. United Kingdom); case regarding the delimitation of the maritime border between Bangladesh and Myanmar in the Bay of Bengal (Bangladesh vs. Myanmar), case M / V "Louisa" (Saint Vincent and Grenadines vs. Kingdom of Spain).

${ }^{10}$ Decision from the 9 th of April 1949, in the case Great Britain vs. Albania.

${ }^{11}$ Decision from the 7 th of September 1927, in the case France vs. Turkey.
} 
France pleaded for the competence of the flag state for solving the case, however the Court admitted that Turkey was also considered competent, as a state whose ship was abandoned, thus it acted accordingly by sanctioning the guilty French officer.

From the decision of the Court it is assumed that the boat is assimilated to the territory of the state: "Except for particular situations determined by international law, ships in the high seas are subjected only to the authority of the state whose flag it addresses. In the virtue of the principle of sea freedom, namely in the absence of sovereignty in the high seas, no state may exercise jurisdictional acts upon foreign ships".

\section{Conclusions}

The people - in the effort to reinforce adequate norms in the process of international cooperation- have and are still manifesting a particular interest for relations in the maritime domain, expressing certain fundamental requirements concerning the rights and responsibilities of each state in using the oceans and seas on the Earth and in expressing the practical forms and methods of cooperating in view of capitalizing the riches they contain. These major aspects were the subject of the UNO Conferences in the last decades.

In the depths of the vast international marine surfaces there is sufficient food for 30 billion people and energetic resources, presently estimated to 160 billion barrels of oil and 14 billion cubic meters of natural gas manganese for 4.000 centuries, cobalt for 200 millenniums.

From the waters of the planetary ocean 4 billion tones of uranium can be "extracted", and in a single year 10 million tones of coal from the underwater mines can be obtained. Likewise, the energy of the sea tides may replace, in a year, the consumption of 70 million tones of coal equivalent, and the total of fishing products "harvested" on the planet is doubled every 10 years.

Taking into consideration the immense potential present in the waters of the planet, it is estimated that, in the next 50 years, the man will be able to freely move across the sea and in the sea, occupying and exploiting it as an integral part of the planet in order to extract minerals, obtain food, as a landfill of waste, for transport operations and, as the population of the globe increases, as a place to live.

For these considerations, a new legal order would be necessary for the international maritime area, which would take into consideration the changes that occurred and lay the possibility of equally capitalizing the immense natural resources.

The debates from the last years revealed the outstanding significance of reinforcing an adequate regime for the oceans and seas on Earth, in the efforts to establish a new economic international order, starting from: the increasingly important place of marine riches in global economy, the importance of maritime spaces for developing interstatal cooperation and the role attributed to the planetary ocean in maintaining peace and security in the world.

\section{Bibliography} 2010;

D. Mazilu, Dreptul internaţional public, 5th Edition, "Lumina Lex" Press, Bucharest,

Gh. Moca, M. Duțu, Dreptul internaţional public, volume I, "Universul Juridic" Publishing, Bucharest, 2008;

Ch. Rousseau, Droit international public, tome IV, Sirey, Paris, 1980;

S. Oda, D.M. Johnston, J.J. Holst, A. Hollick, M. Hardy, A New Regime for the Oceans, The Triangle Papers, 1976;

V. Gliga, Peaceful uses of ocean space: zones of peace and security, Statement at 68th Plenary Meeting at Third United Nations Conference on the Law of the Sea, Official Records, vol. I, New York, 1976;

D. Coulmy, J. P. Page, Les ressources de l'océan, mythe ou réalité?, Presses de la Cité, Paris, 1974; 
I. Brownlie, Principles of Public International Law, Second Edition, Oxford University Press, New York, 1973;

J. Andrassy, International Law and the Resources of the Sea, Columbia University Press, New York and London, 1970;

S. Oda, International Law of the Resources of the Sea, Hague Academy of International Law, 1969. 